\title{
FIELD EVALUATION OF WATER OR CITRATE SOLUBLE PHOSPHORUS IN MODIFIED PHOSPHATE ROCKS FOR SOYBEAN
}

\author{
Luís Ignácio Prochnow ${ }^{1 *}$; José Francisco da Cunha²; Ariel Francisco Candiotti Ventimiglia ${ }^{3}$ \\ ${ }^{1}$ Depto. de Solos e Nutrição de Plantas - USP/ESALQ - C.P. 9 - CEP: 13418-900 - Piracicaba, SP. \\ ${ }_{3}^{2}$ Tecfértil, Av. Eliseu de Almeida, 1527 - CEP: 05533-000 - São Paulo, SP. \\ ${ }^{3}$ Galvani Fertilizantes da Bahia, Rod. Br 020 Km 526 - CEP: 47800-974 - Barreiras, BA. \\ ${ }^{*}$ Corresponding author <liprochn@carpa.ciagri.usp.br>
}

\begin{abstract}
Ten P fertilizers were collected (commercial fertilizers) or synthesized (experimental sources) in order to obtain single superphosphates varying in water and citrate solubility. A standard source of $P$ was also produced by crystallization of the water-soluble fraction of a triple superphosphate. Eleven $P$ sources were band applied to a medium textured Xanthic Hapludox, in Bahia, Brazil (low content of resin-extractable P) at a rate of $80 \mathrm{~kg} \mathrm{ha}^{-1}$ of $\mathrm{NAC}+\mathrm{H}_{2} \mathrm{O}$ (neutral ammonium citrate plus water) soluble $\mathrm{P}_{2} \mathrm{O}_{5}$, with soybean as the crop which was grown to maturity. A check plot (control) was included in the study. Three of the $P$ sources [single superphosphate produced from Araxa phosphate rock (PR), low-grade single superphosphate produced from Lagamar PR and the standard source of P] were also applied at rates to provide 40 and $120 \mathrm{~kg} \mathrm{ha}^{-1}$ of NAC + $\mathrm{H}_{2} \mathrm{O}$ soluble $\mathrm{P}_{2} \mathrm{O}_{5}$. Yield of soybean was evaluated by analysis of variance with mean comparison performed utilizing LSD lines, considering the $\mathrm{P}$ sources applied at a rate of $80 \mathrm{~kg} \mathrm{ha}^{-1}$ of $\mathrm{P}_{2} \mathrm{O}_{5}+$ control. Regression procedures were used to study the relation between yield of soybean and rates of $\mathrm{P}_{2} \mathrm{O}_{5}$. The fertilizers tested performed equally well as a source of $P$ for soybean. The level of water-soluble $P$ did not influence fertilizer performance.
\end{abstract}

Key words: acidulated phosphates, available $\mathrm{P}$, phosphorus sources, water-insoluble $\mathrm{P}$

\section{AVALIAÇÃO AGRONÔMICA DO FÓSFORO SOLÚVEL EM ÁGUA OU CITRATO DE FOSFATOS DE ROCHA ACIDULADOS PARA A SOJA}

\begin{abstract}
RESUMO: Dez fontes de P foram coletadas em unidades revendedoras de fertilizantes comerciais ou produzidas em laboratório de tal forma a obter superfosfatos simples com variabilidade em água e citrato neutro de amônio + água ( $\left.\mathrm{CNA}+\mathrm{H}_{2} \mathrm{O}\right)$. Utilizou-se como fonte padrão de fósforo a fração solubilizada, filtrada e cristalizada de um superfosfato triplo. As onze fontes de $\mathrm{P}$ foram aplicadas nas linhas de semeadura de soja de um Xanthic Hapludox textura média, localizado no Município de Barreiras, Bahia (baixo teor de fósforo resina) na dose de $80 \mathrm{~kg} \mathrm{ha}^{-1}$ de $\mathrm{P}_{2} \mathrm{O}_{5}$ solúvel em $\mathrm{CNA}+\mathrm{H}_{2} \mathrm{O}$. Três das fontes (superfosfatos simples produzido a partir da rocha fosfática de Araxá e Lagamar e a fonte padrão) foram aplicadas também em doses de 40 e $120 \mathrm{~kg} \mathrm{ha}^{-1}$ e uma parcela testemunha, sem $\mathrm{P}$, adicionada ao experimento. A produtividade da soja foi avaliada por meio de análise de variância e comparação de médias, considerando-se as fontes de $\mathrm{P}$ aplicadas na dose de $80 \mathrm{~kg} \mathrm{ha}^{-1} \mathrm{P}_{2} \mathrm{O}_{5}$ + parcela testemunha. Regressões foram utilizadas para estudar a relação entre a produtividade de soja e as doses de $\mathrm{P}_{2} \mathrm{O}_{5}$. Os fertilizantes tiveram igual comportamento como fonte de $\mathrm{P}$ às plantas de soja. $\mathrm{O}$ teor de $\mathrm{P}_{2} \mathrm{O}_{5}$ solúvel em água não influenciou o comportamento dos fertilizantes.
\end{abstract}

Palavras-chave: fosfatos acidulados, $\mathrm{P}$ disponível, fontes de fósforo, fósforo insolúvel em água

\section{INTRODUCTION}

When phosphate rocks (PR) are acidulated to form more soluble $\mathrm{P}$ fertilizers, $\mathrm{P}$ compounds are formed other than the desired $\mathrm{NH}_{4}$ and $\mathrm{Ca}$ phosphates. Exhaustion of high-grade phosphate rock throughout the world will certainly increase the levels of impurity compounds, generally water-insoluble, in the final acidulated P fertilizers (Lehr, 1984). In Brazil, acidulated $P$ fertilizers have been produced from low-grade PR due to high amounts of impurities, especially iron-aluminum oxides, present in the ore.

The presence of $\mathrm{Fe}-\mathrm{Al}$ impurities in the final acidulated $P$ fertilizer has raised the concern that the insoluble $\mathrm{P}$ compounds would decrease the agronomic effectiveness of the fertilizers due to a decrease in watersolubility of such fertilizers (Sikora \& Giordano, 1995). Based on this concept the European Economic Community set a level of $93 \%$ of the ammonium citrate-soluble $P$ as water-soluble $\mathrm{P}$ in fully acidulated $\mathrm{P}$ fertilizers market in the European Community (Council, 1976) but Johnston (1999), in a literature review, commented that there is no scientific basis for requiring such a high level of watersoluble $P$.

In the USA some studies have shown that the levels of impurity compounds currently in triple superphosphates and mono-ammonium phosphates produced in that country did not have a detrimental effect 
on P availability to potatoes (Mullins \& Evans, 1990) and pearl millet (Mullins \& Sikora, 1990) in field trials and to maize (Mullins, 1988) and sorghum sudangrass (Sikora et al., 1989) in greenhouse studies. Mullins \& Evans (1990) evaluated four commercial triple superphosphates sources containing various levels of water-soluble $P(81$ to $94 \%$ of AOAC available $P$ as water-soluble $P$ ) and concluded that yield of potatoes was not affected by the source of $P$ and also that the fertilizer performance was not influenced by the level of water-soluble P. Similar results were obtained by Mullins \& Sikora (1990) in ten sources of monoammonium phosphates containing from 81 to $100 \%$ water-soluble $\mathrm{P}$ (in the AOAC available $\mathrm{P}$ ) to pearmillet.

Prochnow et al. (1998) compared the efficiency of four experimental $P$ sources, produced from Brazilian apatite concentrate varying in their content of iron and aluminum oxides, in its original and water-insoluble form. The authors concluded that the $\mathrm{P}$ availability of the water-insoluble fraction was generally lower than the original $P$ source and that higher amounts of iron and aluminum oxides lead to lower performance of the water-insoluble fraction.

In Brazil, single superphosphates (SSP) have to contain $18 \%$ and $16 \%$ (tolerance of $10 \%$ minus), respectively, of $\mathrm{P}_{2} \mathrm{O}_{5}$ soluble in neutral ammomium citrate + water $\left(\mathrm{NAC}+\mathrm{H}_{2} \mathrm{O}\right)$ and water in order to be commercialized (Brasil, 1982). These standards discard some PRs or apatite concentrates as potential sources to produce acidulated $P$ fertilizers. Furthermore, some materials or industrial processes utilized in order to produce SSP with better physical properties, or containing micronutrients, interfere with the water solubility of the final product and these processes should also be evaluated concerning the performance of the modified products in terms of $\mathrm{P}$ availability to plants.

The objective of this study was to evaluate the effectiveness of various commercial and experimental acidulated $P$ fertilizers, varying in water and citrate solubility, and produced following the procedure to obtain single superphosphates, in order to provide $\mathrm{P}$ to soybean plants under field condition.

\section{MATERIAL AND METHODS}

\section{Phosphorus sources}

Ten $P$ sources ${ }^{1}$ were produced utilizing the process to obtain SSP (TABLES 1 and 2). It can be noticed that three of the products were in the powder form (FAR, FFM and FC), six granulated and screened to pellets particle size of 1.7 $3.35 \mathrm{~mm}$ (FL, DUR, MR, FI, FS and EK) and one granulated to pellets particle size of $0.5-1.41 \mathrm{~mm}$ (FMG). In some of the $\mathrm{P}$ sources materials were added, such as $\mathrm{MgO}$, Concinal (obtained from the algae Lhithothamium) and micronutrients, or processes modified, in order to evaluate the improvement in the physical properties of the fertilizers (FFM, FC, FMG, DUR and MR). A standard source of $P$ was produced by crystallization of the water-soluble fraction of a triple superphosphate - FMC.

\section{Field Evaluation of the $P$ sources}

Field evaluation was conducted in Barreiras, Bahia, Brazil, in a medium-textured, Xanthic Hapludox containing $59 \%, 5 \%$ and $36 \%$ of sand, silt and clay, respectively. Resinextractable P (Raij \& Quaggio, 1983) was $9 \mathrm{mg} \mathrm{dm}^{-3}$ and Mehlich-1 P (Mehlich, 1953) was $5 \mathrm{mg} \mathrm{dm}^{-3}$ which both corresponds to a low soil test level. The amounts of $\mathrm{Ca}, \mathrm{Mg}$, $\mathrm{K}, \mathrm{H}+\mathrm{Al}$ and $\mathrm{Al}$ were respectively 2.3, 0.9, 0.1, 1.8 and 0.0 $\mathrm{cmol}_{\mathrm{c}} \mathrm{dm}^{-3}$. Cation-exchange capacity was $5.1 \mathrm{cmol}_{\mathrm{c}} \mathrm{dm}^{-3}$ and $\mathrm{pH}$ in $0.01 \mathrm{~mol} \mathrm{~L}^{-1} \mathrm{CaCl}_{2}$ (2.5 solution:soil ratio) was 5.2 . Potassium was added as basal dressing at a rate of $150 \mathrm{~kg}$ $\mathrm{ha}^{-1} \mathrm{~K}$ as $\mathrm{KCl}$. Calcium sulfate dihydrate (gypsum) and a product containing micronutrients $(5 \% \mathrm{Zn}, 3 \% \mathrm{~B}, 6 \% \mathrm{Cu}, 5 \%$ Fe and $17.5 \% \mathrm{Mn}$ ) were also added at rates of 400 and 40 $\mathrm{kg} \mathrm{ha}^{-1}$, respectively. These fertilizers were broadcast and incorporated to a soil depth of $8 \mathrm{~cm}$. The amounts of nutrients applied as basal application were adequate to discard any potential side-effect when comparing the $\mathrm{P}$ sources.

Phosphorus sources and the standard FMC were localized in the line $(3 \mathrm{~cm}$ below and $2 \mathrm{~cm}$ besides the seeds) at a rate to supply $80 \mathrm{~kg} \mathrm{ha}^{-1} \mathrm{P}_{2} \mathrm{O}_{5}$ of $\mathrm{NAC}+\mathrm{H}_{2} \mathrm{O}$ soluble $\mathrm{P}_{2} \mathrm{O}_{5}$. The rate of $\mathrm{P}_{2} \mathrm{O}_{5}$ was chosen based on the $P$ status of the soil in order to provide sufficient phosphorus for high yield of soybean and was based on the literature (EMBRAPA, 1998). The $P$ sources were applied based on the $\mathrm{NAC}+\mathrm{H}_{2} \mathrm{O}$ available $\mathrm{P}_{2} \mathrm{O}_{5}$ instead of total $\mathrm{P}_{2} \mathrm{O}_{5}$ since phosphate fertilizers in Brazil are marketed on the basis of their $\mathrm{NAC}+\mathrm{H}_{2} \mathrm{O}$ available $\mathrm{P}_{2} \mathrm{O}_{5}$ content. By applying 80 kg ha ${ }^{-1} \mathrm{NAC}+\mathrm{H}_{2} \mathrm{O}$ soluble $\mathrm{P}_{2} \mathrm{O}_{5}$, total $\mathrm{P}_{2} \mathrm{O}_{5}$ and watersoluble $\mathrm{P}_{2} \mathrm{O}_{5}$ were applied, respectively, in the range of 81.4 -101.6 and $18.7-72.32 \mathrm{~kg} \mathrm{ha}^{-1}$.

In order to test some of the products in a range of rates (response curve) the $\mathrm{P}$ sources FL, FS and the standard source of $P$ were also applied in rates of 40 and $120 \mathrm{~kg} \mathrm{ha}^{-1} \mathrm{P}_{2} \mathrm{O}_{5}$. A check plot control (no $\mathrm{P}$ applied) was also included. The $P$ sources and rates were arranged in a randomized complete-block design with three replications. Field plots consisted of four rows, $4 \mathrm{~m}$ long and spaced at $0.5 \mathrm{~m}$.

Seeds of soybean (Glycine max, cultivar FT 103) were inoculated with Rhizobium japonicum and treated with $17 \mathrm{~g}$ of Mo and $2 \mathrm{~g}$ Co per $50 \mathrm{~kg}$ of seeds and sown in november 24, 1998, at the rate of 15 seeds per meter.

Soybean grain was manually harvested in April 08, 1999, from the 2 meters of the two central rows and the yield calculated.

\footnotetext{
${ }^{1}$ The term $\mathrm{P}$ source was preferred since many of the fertilizers tested do not follow the standards to be classified as single
} superphosphates according to the current Brazilian legislation (Brasil, 1982),. 
TABLE 1 - Phosphate rocks utilized, pellet particle size (PPS) and details on the production of the P sources.

\begin{tabular}{|c|c|c|c|}
\hline$P$ source & PR & PPS & Production \\
\hline FMC & Tapira & Granules, $1.7-3.35 \mathrm{~mm}$ & Crystallized fraction of the leached triple superphosphate with water \\
\hline FAR & Lagamar & Powder, $<0.5 \mathrm{~mm}$ & $\begin{array}{l}\text { Product of the reaction between Lagamar } \mathrm{PR} \text { and } \mathrm{H}_{2} \mathrm{SO}_{4} \text { with the } \\
\text { objective of producing SSP, not granulated }\end{array}$ \\
\hline FFM & Lagamar & Powder, $<0.5 \mathrm{~mm}$ & $\begin{array}{l}\text { Addition of } 1.1 \% \text { of } \mathrm{MgO} \text { to FAR in order to reduce the free acidity } \\
\text { and humidity }\end{array}$ \\
\hline FC & Lagamar & Powder, $<0.5 \mathrm{~mm}$ & $\begin{array}{l}\text { Addition of } 30 \% \text { of Concinal (obtained from the algae Lhithothamium) } \\
\text { to FAR in order to reduce the free acidity and humidity }\end{array}$ \\
\hline $\mathrm{FL}$ & Lagamar & Granules, $1.7-3.35 \mathrm{~mm}$ & Same as FAR but granulated \\
\hline FMG & Lagamar & Granules, $0.5-1.41 \mathrm{~mm}$ & Same as FAR but micro granulated \\
\hline DUR & Lagamar & Granules, $1.7-3.35 \mathrm{~mm}$ & Produced as FAR but over dried in order to obtain harder granules \\
\hline MR & Lagamar & Granules, $1.7-3.35 \mathrm{~mm}$ & $\begin{array}{l}\text { Produced as FAR, ground and granulated again at low temperature in } \\
\text { order to obtain a more friable SSP }\end{array}$ \\
\hline $\mathrm{FI}$ & Lagamar & Granules, $1.7-3.35 \mathrm{~mm}$ & $\begin{array}{l}\text { Addition of micronutrients }(0.2 \% \mathrm{Zn}, 0.12 \% \mathrm{~B}, 0.24 \% \mathrm{Cu}, 0.70 \% \mathrm{Mn} \\
\text { and } 0.70 \% \mathrm{Fe}) \text { to FAR }\end{array}$ \\
\hline FS & Araxá & Granules, $1.7-3.35 \mathrm{~mm}$ & $\begin{array}{l}\text { Product of the reaction between Araxá PR and } \mathrm{H}_{2} \mathrm{SO}_{4} \text { with the } \\
\text { objective of producing SSP, granulated }\end{array}$ \\
\hline EK & $\begin{array}{l}\text { Imported } \\
\text { (Togo) }\end{array}$ & Granules, $1.7-3.35 \mathrm{~mm}$ & $\begin{array}{l}\text { Product of the reaction between the imported Togo } \mathrm{PR} \text { and } \mathrm{H}_{2} \mathrm{SO}_{4} \\
\text { with the objective of producing } \mathrm{SSP} \text {, granulated }\end{array}$ \\
\hline
\end{tabular}

TABLE 2 - Chemical analysis of the P sources.

\begin{tabular}{|c|c|c|c|c|c|c|}
\hline \multirow[t]{2}{*}{$\begin{array}{c}P \\
\text { source }^{(1)}\end{array}$} & \multicolumn{3}{|c|}{$\mathrm{P}_{2} \mathrm{O}_{5}$} & \multirow[t]{2}{*}{$\mathrm{Al}_{2} \mathrm{O}_{3}$} & \multirow[t]{2}{*}{$\mathrm{Fe}_{2} \mathrm{O}_{3}$} & \multirow[t]{2}{*}{$\mathrm{fi}^{(2)}$} \\
\hline & Total & $\mathrm{NAC}+\mathrm{H}_{2} \mathrm{O}$ & $\mathrm{H}_{2} \mathrm{O}$ & & & \\
\hline & \multicolumn{6}{|c|}{ - --1 } \\
\hline FMC & 48.2 & 47.4 & 40.9 & 1.7 & 1.6 & 86.3 \\
\hline FAR & 18.9 & 16.5 & 11.7 & 2.1 & 0.8 & 70.9 \\
\hline FFM & 16.9 & 15.5 & 10.0 & 1.9 & 0.7 & 64.5 \\
\hline $\mathrm{FC}$ & 15.2 & 13.3 & 3.1 & 1.9 & 0.8 & 23.3 \\
\hline $\mathrm{FL}$ & 20.9 & 18.0 & 13.1 & 2.3 & 0.9 & 72.7 \\
\hline FMG & 21.2 & 16.7 & 13.0 & 2.4 & 0.9 & 77.8 \\
\hline DUR & 22.8 & 18.1 & 10.7 & 2.1 & 1.1 & 59.1 \\
\hline MR & 20.5 & 17.0 & 13.6 & 2.1 & 0.9 & 80.0 \\
\hline $\mathrm{FI}$ & 19.2 & 17.0 & 12.0 & n.d. & n.d. & 70.6 \\
\hline FS & 20.4 & 19.2 & 15.4 & 0.5 & 1.5 & 80.2 \\
\hline EK & 20.2 & 17.7 & 16.0 & 0.5 & 0.4 & 90.4 \\
\hline
\end{tabular}

(1) FMC: standard source of P; FAR: SSP produced from Lagamar PR; FFM: addition of $1.1 \% \mathrm{MgO}$ to FAR; FC: Addition of $30 \%$ concinal to FAR; FL: Granulated FAR; FMG: Microgranulated FAR; DUR: Over dried FAR; MR: friable FAR; FI: Addition of micronutrients to FAR; FS: SSP produced from Araxá PR; EK: SSP produced from Togo PR.

(2) $\mathrm{fi}=$ percentage of water-soluble $\mathrm{P}_{2} \mathrm{O}_{5}$ in the $\mathrm{NAC}+\mathrm{H}_{2} \mathrm{O}$-soluble $\mathrm{P}_{2} \mathrm{O}_{5}$. n.d.:not determined; similar contents of $\mathrm{Al}_{2} \mathrm{O}_{3}$ and $\mathrm{Fe}_{2} \mathrm{O}_{3}$ should be expected as those presented by the FAR or FL.

\section{Data Analysis}

Yield of soybean was analyzed considering: (a) analysis of variance for the control (no $P$ applied) $+P$ sources treatments applied at only one rate $\left(80 \mathrm{~kg} \mathrm{ha}^{-1} \mathrm{P}_{2} \mathrm{O}_{5}\right)$ with means comparison performed utilizing LSD (least significant difference) lines; (b) analysis of variance considering only the treatments where $\mathrm{P}$ was applied (control was excluded); (c) regression procedures for the factorial design between three $\mathrm{P}$ sources (FMC, FS and $\mathrm{FL})$ and four rates of $\mathrm{P}_{2} \mathrm{O}_{5}\left(0,40,80\right.$ and $\left.120 \mathrm{~kg} \mathrm{ha}^{-1}\right)$. All the data analysis was performed using SAS software (SAS, 1985).

For the relation between yield of soybean and rates of $\mathrm{P}_{2} \mathrm{O}_{5}$ a dummy variable multiple regression analysis was performed. This resulted in a common intercept and a single value of MSE and $R^{2}$ for the three regression equations (one for each $\mathrm{P}$ source). Three models (linear, semi-log and square root) were tested to describe the relationship between the parameters studied, and the one presenting the higher $R^{2}$ chosen.

The relative agronomic effectiveness (RAE) was calculated for each $P$ source. RAE was definied as the ratio of the two slopes:

$$
R A E i=\frac{\beta i}{\beta F M C} x 100
$$

where $\beta i$ is the slope of the response function of the $P$ sources tested and $\beta F M C$ is the slope of the response function of the standard - FMC. This expression ranks the $P$ sources with respect to FMC according to their agronomic potential to produce a yield response (Chien et al., 1990).

In order to evaluate if there was statistical significant difference between the three phosphorus sources in the range of rates applied a $\mathrm{F}$ value $\left(=t^{2}\right)$ was calculated according to the formula:

$$
t=\frac{|\beta i a-\beta i b|}{\sqrt{(S E(\beta i a))^{2}}+(S E(\beta i b))^{2}}
$$


where $\beta_{\mathrm{ia}}$ is the slope of the response function for the first $P$ source tested, $\beta_{\text {ib }}$ is the slope for the second $P$ source tested, $\operatorname{SE}\left(\beta_{\mathrm{ia} a}\right.$ is the standard error for $\beta_{\mathrm{ia}}$ and $\operatorname{SE}\left(\beta_{\mathrm{ib}}\right)$ is the standard error for $\beta_{\mathrm{ib} \text {. }}$.

\section{RESULTS AND DISCUSSION}

\section{Characteristics of the $P$ sources}

The $\mathrm{P}$ sources, excluding the standard source, presented high variability for $\mathrm{NAC}+\mathrm{H}_{2} \mathrm{O}$ soluble $\mathrm{P}_{2} \mathrm{O}_{5}(13.3$ - $19.2 \%)$, water-soluble $\mathrm{P}_{2} \mathrm{O}_{5}(3.1 \%-16.0 \%)$ and percentage of water-soluble $\mathrm{P}_{2} \mathrm{O}_{5}$ in the $\mathrm{NAC}+\mathrm{H}_{2} \mathrm{O}$ fraction (23.3 -90.4\%; TABLE 2), showing that the processes and materials, including the PR, used in the production of the $P$ sources interfere in the solubility of the fertilizers. Actually, based on current Brazilian legislation only two of the ten $P$ sources (EK and $F S$ ) meet the requirement to be commercialized as single superphosphates (at least $14.4 \%$ of water-soluble $\mathrm{P}_{2} \mathrm{O}_{5}$ ). $\mathrm{FC}$ was the $\mathrm{P}$ source with the lowest water-soluble $\mathrm{P}_{2} \mathrm{O}_{5}$ due probably to the presence of dicalcium phosphate. The percentage of water-soluble $\mathrm{P}_{2} \mathrm{O}_{5}$ in the $\mathrm{NAC}+\mathrm{H}_{2} \mathrm{O}$ fraction in the standard source of $\mathrm{P}(86.3 \%)$ was low considering that in the solution leached the only $\mathrm{P}$ form expected was the monocalcium phosphate monohydrate. Two possibilities exist to explain this result: (i) water-insoluble forms of Fe-Al-P still remaining among the crystals of monocalcium phosphate monohydrate and (ii) the formation of dicalcium phosphate (monetite), which is not water-soluble, during the process of crystallization. The presence of $1.6 \%$ of $\mathrm{Fe}_{2} \mathrm{O}_{3}$ and $1.7 \%$ of $\mathrm{Al}_{2} \mathrm{O}_{3}$ in the product obtained after crystallization reinforces the statement (i) as the possible cause for the presence of forms of water-insoluble $\mathrm{P}$ compounds.

\section{Field evaluation}

Yield of soybean was significantly affected when considering the control + eleven $P$ sources applied $(80 \mathrm{~kg}$ $\left.\mathrm{ha}^{-1}\right)$ as the independent variables $(\mathrm{p} \leq 0.05)$ but the comparison of means by LSD lines showed that the only significant difference was met between the control with all the P sources: control < all P sources (TABLE 3 ). When the control was excluded and just the eleven $P$ sources considered in the analysis of variance still no effect of $P$ source was detected. No significant relation was found between the amounts of total $\mathrm{P}_{2} \mathrm{O}_{5}$ or watersoluble $\mathrm{P}_{2} \mathrm{O}_{5}$ applied and yield of soybean (Figure 1).

TABLE 3 - Yield of soybean as affected by the application of $\mathrm{P}_{2} \mathrm{O}_{5}$ from different $\mathrm{P}$ sources.

\begin{tabular}{lccc}
\hline P source $^{(1)}$ & $\begin{array}{c}\text { Yield of } \\
\text { soybean }\end{array}$ & LSD lines $1^{(2,4)}$ & LSD lines $2^{(3,4)}$ \\
\hline Control & 1775.3 & $\mathrm{~B} \mathrm{~h}^{-1}$ & \\
FMC & 3363.2 & $\mathrm{~A}$ & $\mathrm{a}$ \\
FAR & 3102.8 & $\mathrm{~A}$ & $\mathrm{a}$ \\
FFM & 3215.0 & $\mathrm{~A}$ & $\mathrm{a}$ \\
FC & 3150.2 & $\mathrm{~A}$ & $\mathrm{a}$ \\
FL & 3332.3 & $\mathrm{~A}$ & $\mathrm{a}$ \\
FMG & 3191.8 & $\mathrm{~A}$ & $\mathrm{a}$ \\
DUR & 3273.3 & $\mathrm{~A}$ & $\mathrm{a}$ \\
MR & 3357.7 & $\mathrm{~A}$ & $\mathrm{a}$ \\
FI & 3220.5 & $\mathrm{~A}$ & $\mathrm{a}$ \\
FS & 3331.8 & $\mathrm{~A}$ & $\mathrm{a}$ \\
EK & 3276.5 & $\mathrm{~A}$ & $\mathrm{a}$ \\
\hline Observations & & 35 & 33 \\
LSD & & 561.28 & 561.34 \\
C.V. (\%) & & 10.2 & 10.1 \\
\hline
\end{tabular}

(1) FMC: standard source of P; FAR: SSP produced from Lagamar PR; FFM: addition of $1.1 \% \mathrm{MgO}$ to FAR; FC: Addition of $30 \%$ concinal to FAR; FL: Granulated FAR; FMG: Microgranulated FAR; DUR: Over dried FAR; MR: friable FAR; FI: Addition of micronutrients to FAR; FS: SSP produced from Araxá PR; EK: SSP produced from Togo PR.

(2) LSD lines 1: mean comparison in the column considering all $P$ sources + check control.

(3) LSD lines 2: mean comparison in the column considering $P$ sources (check control excluded).

(4) Values followed by the same letter in the column are not statistically different $(p \leq 0.05)$.

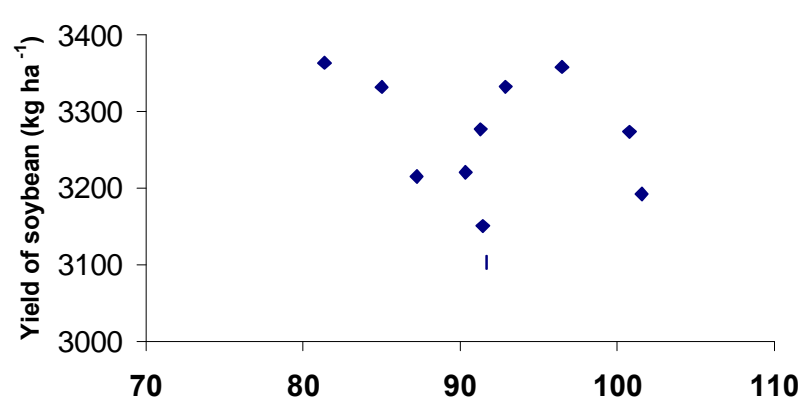

A

Amount of total $\mathrm{P}_{2} \mathbf{O}_{5}$ applied $\left(\mathrm{kg} \mathrm{ha}^{-1}\right)$

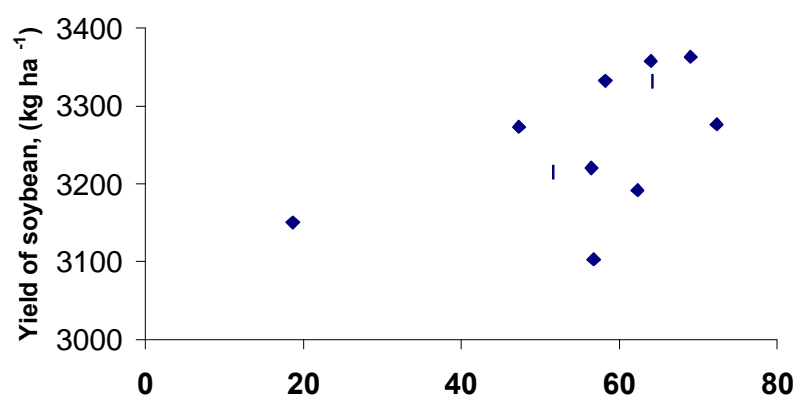

B

Amount of water-soluble $\mathrm{P}_{2} \mathrm{O}_{5}$ applied, $\left(\mathrm{kg} \mathrm{ha}^{-1}\right)$

Figure 1 - Yield of soybean as affected by the amount of total $\mathrm{P}_{2} \mathrm{O}_{5}(A)$ and water-soluble $\mathrm{P}_{2} \mathrm{O}_{5}(B)$, considering the eleven $P$ sources. 
The differences in water-soluble $P$ presented by the $P$ sources do not interfere with the yield of soybean considering the application of $80 \mathrm{~kg} \mathrm{ha}^{-1} \mathrm{P}_{2} \mathrm{O}_{5}$, which is the recommended rate of $\mathrm{P}_{2} \mathrm{O}_{5}$ to be applied to this crop taking into account the available $P$ status of the soil (EMBRAPA, 1998). Products classified or not as single superphosphates by the Brazilian legislation had similar efficiency in providing $\mathrm{P}$ to the soybean plants.

The objective of this study was not to evaluate the processes used in the production of the $P$ sources concerning possible improvement in the physical properties of the fertilizers, but to find out if these processes, which interfere in the water-solubility, would also interfere in the agronomic effectiveness of the $P$ fertilizers to provide phosphorus to the plants.

The semi-logarithmic model better described the relation between yield of soybean and the rate of $\mathrm{P}_{2} \mathrm{O}_{5}$ (TABLE 4 and Figure 2). The RAE for the three $P$ sources tested were respectively of 100,103 and $96 \%$ for the FMC, FS and FL (TABLE 5). As no statistical difference was found in yield of soybean provided by the three $P$ sources only one model was adjusted to express the relation between yield and rates of $\mathrm{P}_{2} \mathrm{O}_{5}$ (Figure 2). FL did not meet the requirement to be considered a single superphosphate but its performance in terms of providing $P$ to the plants was not statistically different than the standard source of $\mathrm{P}$ and a single superphosphate which is in agreement with the legislation (Brasil, 1982).

The results obtained in this study agree with those reported by Mullins \& Evans (1990) and Mullins \& Sikora (1990). These authors also found that variance in the watersolubility of fully acidulated $P$ fertilizers (81 to $94 \%$ of AOAC available $P$ as water-soluble $P$ for triple superphosphates and 81 to $100 \%$ for monoammonium phosphates) did not affect yields and that fertilizer performance was poorly affected by the level of water-soluble P.

New field studies are encouraged in order to clarify the necessity of high water-solubility in fully acidulated $P$

TABLE 4 - Regression estimates for the semi-logarithmic model adjusted describing the relation between yield of soybean as affected by source and rate of $\mathrm{P}_{2} \mathrm{O}_{5}$.

\begin{tabular}{lcc}
\hline \multicolumn{1}{c}{ P source $^{(1)}$} & Estimate & Value of estimate \\
\hline Intercept & $\beta_{0}$ & 1775.25 \\
FMC & $\beta_{1}$ & $337.85^{* *}$ \\
FS & $\beta_{2}$ & $347.71^{* *}$ \\
FL & $\beta_{3}$ & $(20.75)$ \\
\hline (1) FMC: standard source of P; FS: SSP produced from Araxá PR; \\
FL: Granulated low-grade SSP produced from Lagamar PR. \\
**significant at 0.01
\end{tabular}

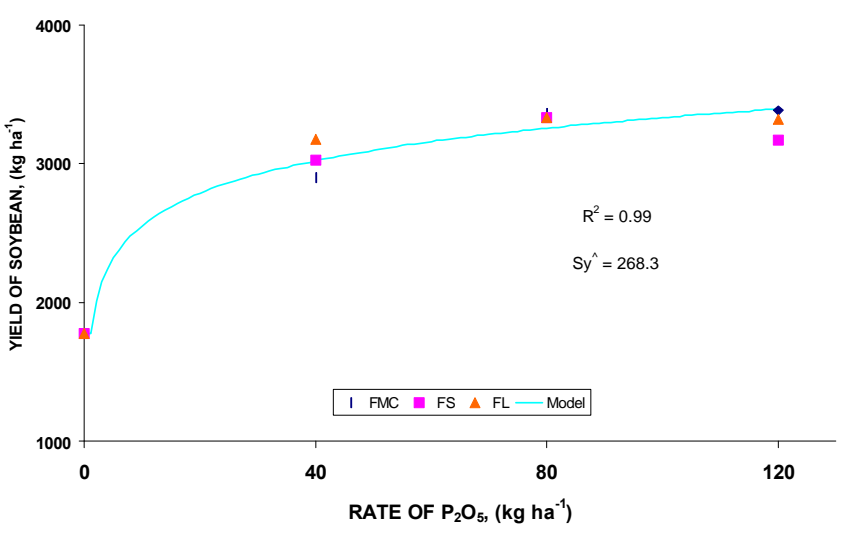

Figure 2 - Yield of soybean as affected by the rate of $\mathrm{P}_{2} \mathrm{O}_{5}$. Models for the three $P$ sources tested were not statistically different $(p \leq 0.05)$.

TABLE 5 - Relative Agronomic Effectiveness (RAE) of each source relative to the standard FMC for yield of soybean.

\begin{tabular}{|c|c|}
\hline$P$ source ${ }^{(1)}$ & RAE \\
\hline & $\%$ \\
\hline FMC & 100 \\
\hline FS & 103 \\
\hline $\mathrm{FL}$ & 96 \\
\hline
\end{tabular}

(1) FMC: standard source of P; FS: SSP produced from Araxá PR; FL: Granulated low-grade SSP produced from Lagamar PR.

fertilizers and also to verify if the standards of watersoluble $\mathrm{P}_{2} \mathrm{O}_{5}$ adopted by the Brazilian legislation are supported by scientific data.

\section{CONCLUSION}

The fertilizers tested performed equally well as source of $P$ for soybean when band applied under field conditions, and the level of water-soluble $P$ did not influence the fertilizer performance.

\section{REFERENCES}

BRASIL. Ministério da Agricultura. Secretaria Nacional de Defesa Agropecuária. Portaria 01 de 04/83; Portaria 03 de 12/06/ 86. Inspeção e fiscalização da produção e do comércio de fertilizantes, corretivos, inoculantes, estimulantes e biofertilizantes destinados à agricultura; legislação e fiscalização. Brasília, 1982. 88p.

CHIEN, S.H.; SALE, P.W.G.; FRIESEN, D.K. A discussion of the methods for comparing the relative effectiveness of phosphate fertilizers varying in solubility. Fertilizer Research, v.24, p.149-157, 1990.

COUNCIL Directive on the Approximation of the Laws of the Member States Relating to Fertilizers. Official Journal of the European Communities, n. L 24, p.21-44, 1976. (Directive, 76/116/EEC).

EMBRAPA. Centro Nacional de Pesquisa de Soja. Recomendações técnicas para a cultura da soja na região central do Brasil. Londrina: EMBRAPA, CNPSo, 1998. 182p. (Documentos, 120). 
JOHNSTON, A.E. Water solubility of phosphatic fertilizers. In: THE FERTILIZER INSTITUTE'S 1999 WORLD FERTILIZER CONFERENCE, New York, 1999. Proceedings. New York: The Fertilizer Institute, 1999. p.1-31.

LEHR, J.R. Impact of phosphate rock quality on fertilizer market uses. Industry and Mineralogy, v.200, p.127-153, 1984.

MEHLICH, A. Determination of $\mathbf{P}, \mathbf{C a}, \mathbf{M g}, \mathbf{K}$, and $\mathrm{NH}_{4}$ by North Carolina soil testing laboratory. Raleigh: North Caroline Department of Agriculture, 1953.

MULLINS, G.L. Plant availability of $P$ in commercial superphosphate fertilizers. Communications in Soil Science and Plant Analysis, v.19, p.1509-1525, 1988.

MULLINS, G.L.; EVANS, C.E. Field evaluation of commercial triple superphosphates fertilizers. Fertilizer Research, v.25, p.101-106, 1990

MULLINS, G.L.; SIKORA, F.J. Field evaluation of commercial monoammonium phosphate fertilizers. Fertilizer Research, v.22, p.1-6, 1990.
PROCHNOW, L.I.; KIEHL, J.C.; RAIJ, B. van. Plant availability of phosphorus in the neutral ammonium citrate fraction of Brazilian acidulated phosphates. Nutrient Cycling in Agroecosystems, v.52, p.61-65, 1998.

RAIJ, B. van; QUAGGIO, J.A. Métodos de análise de solo para fins de fertilidade. Campinas: Instituto Agronômico, 1983. $31 \mathrm{p}$.

SAS Institute. SAS for linear models: a guide to the ANOVA and GLM procedures. Cary: Statistical Analysis System Institute, 1985.

SIKORA, F.J.; DILLARD, E.F.; COPELAND, J.P. Chemical characterization and bioavailability of phosphorus in waterinsoluble fractions of three mono-ammonium phosphate fertilizers. Journal of the Association of Official Analytical Chemistry, v.72, p.852-856, 1989.

SIKORA, F.J.; GIORDANO, P.M. Future directions for agricultural phosphorus research. Fertilizer Research, v.41, p.167-178, 1995

Received March 13, 2000 